\title{
Psyche, Santa Fe, and the Earth
}

\author{
David G. Barton, Ph.D.*
}

Northern New Mexico College

\begin{abstract}
Santa Fe, New Mexico, is a unique city with an indigenous and multicultural history that serves as a case study for earth-psyche relationships, but it is also an image that encompasses many of the problems and complexes of Western Civilization. This article explores the many underground aspects of the image of "Santa Fe," including the attraction so many people feel for its mythos and the way it represents a new type of relationship to psyche and earth. At the same time, the paper reveals the projections and complexes that outsiders bring to Santa Fe with often toxic results.
\end{abstract}

A few years ago, a colleague described Santa Fe as two separate entities. ${ }^{\mathrm{i}}$ The first is the literal town, possessing a city council and some 60,000 residents. The second, which he called "Santa Fe" is not a literal place but an image, a mystique that casts a powerful spell over those who visit. The mystique of "Santa Fe" refers to something quite specific. People speak of the Santa Fe style, especially in architecture or city planning. Hyundai makes an SUV by that name, and Chris Wilson, a professor of architecture at the University of New Mexico, has referred to "The Myth of Santa Fe." At the heart of this symbol we seem to find a particular idea, perhaps even a model, of our relationship with the earth. I also think that the image has a teleological impulse with some potential for healing, one which, unfortunately, is easily perverted or turned into kitsch, sentimentality, or imitation.

Before going any further, consider a couple of iconic images that are associated in the public mind with New Mexico, keeping an eye out for the underlying enchantment. We start by noticing the foreignness of the culture evoked, both the ethos of Old Spain, so long present on the land, and the philosophies of Pueblo and Navajo people who live here - cultures that are earthy, earth-based, and engaged in what Jerome Bernstein has called a system of "reciprocity" rather than "dominion." As Bernstein suggests in Living in the Borderland, dominion is both the primary myth of Western Civilization and a style of consciousness aimed at conquering nature (20-23). This thrust towards dominion forms a crucial part of the creation story in Genesis, in which God commands Adam (and perhaps Eve) to rule over all living beings (Gen. 1:28). In Bernstein's view, this commandment in Genesis

*dgs.barton@gmail.com 
represents a fundamental shift in human consciousness, one characterized by a separation of ego from nature. Although this form of consciousness is central to the three Abrahamic religions, it is fundamentally alien to the Native American traditions of the American Southwest.

The Santa Fe style can be found in the photographs of Ansel Adams, including his famous image of Hernandez, New Mexico, which reveals the humility of the man-made environment. The photograph is taken from a high point above the village and a small, wind-swept cemetery, emphasizing not the towering achievements of humanity but its precarious hold on the world. Another example of the style comes from the paintings of Georgia O'Keefe. Her most iconic image is probably the Catholic church at Ranchos de Taos, an image that allows us to witness the genesis of the Santa Fe mystique. No great bell towers or spires can be found in this rendering of Catholicism, no great cathedrals or testimonies to the power of human creation. What one notices are the thick mud walls, the round buttresses of "Mother Earth" holding up the basilica. The painting emphasizes not plum lines but surfaces that seem feminine, curved, organic, swelling as if pregnant with life, suggesting a syncretic view of life that has been influenced by the Pueblo tradition, with its underground Kiva ceremonies, and by the Penitente moradas, whose basement "mysteries" are restricted to those living inside its "underground" brotherhood.

In these paintings Santa Fe refers to "earthen," "earthy," and "from the earth." I suspect something further, a hidden connection to the sipapu, the umbilical cord of the world, and the earth as a place of emergence. Physically, the sipapu refers to a small hole or indentation found in the floor of a Pueblo ceremonial room, or kiva, representing the point from which First People emerged from the earth. It is a sacred point, emblematic of the power of the earth and carrying the potential for spiritual regeneration and renewal, the restoration of order and balance that lies at the root of all Pueblo ceremony. The sipapu finds its corollary in many traditions but has the advantage of being connected to a culture that has never recognized a separation between human beings and the natural world, nor the opposition between sacred and profane, ego and unconscious. As C. G. Jung himself understood, the concept of the unconscious does not apply in Pueblo life because there was never a moment when the ego was split from its source. See, for example, Memories, Dreams, and Reflections, pp. 246-53.

A similar pattern can be found in the paintings of Navajo artist R. C. Gorman, the great Native American artist. These paintings, which have their own history in founding the New Mexico style, feel round, full, and alive, stressing both earth and what we might call communion. Underneath the paintings is a land-based ethos, a celebration of the feminine, of the earth as a healing power, rather than as an object requiring the control and dominion of "man." 
Such art provides a visual metaphor for attitudes about the land, but perhaps it also hints at stories. I am thinking, for instance, of the Pueblo and Navajo stories of emergence, so different from the patterns we see in Western civilization. As we all know, a central element in Greek, Roman, and Sumerian mythologies is the journey to the underworld undertaken by the great heroes, sometimes ostensibly to search out a specific individual but always also to gain vision or knowledge, a theme repeated in the ancient rite of the nekyia, in which one communicated with shades of the underworld to question them about the future. ${ }^{\text {ii }}$ For the Hopi, Pueblo, and Navajo, there is no equivalent. There is no need for the hero to seek the underworld because he already possesses its perspective, a perspective embedded in the story of origin. Originally the people lived in the First World, in the world of the dark earth. When that world was destroyed, they moved into the Second World, and so on, until they emerged into this one. The Western hero journeys to the underworld for renewal, but the Pueblo and Navajo have no similar need. In Pueblo life, for instance, everyone remains connected to the dark earth through the kiva, itself located underground in many tribes.

Perhaps we could imagine that "Santa Fe" as a symbol also contains its own kiva, its own connection to the underworld. One feels this connection in the architecture, the mud-adobe homes, old oaken doors, Spanish-Moorish courtyards and high desert gardens. To what does such a connection refer? Here we can only point a finger to a spot just beyond the horizon of rational thinking. We find equivalents in every culture imaginable, including the Jungian tribe, whose theoretical concept of the ego-Self axis represents a similar psychological reality. The rapture felt by tourists as they walk through the city is a form of participation mystique that seems to be conjured by the elements of the city, promising that everyone who walks the street will find an umbilical cord to provide nourishment against the existential crises of the post-modern world.

Joseph Campbell says in his interviews with Bill Moyers that we can tell a great deal about a culture by the stories it tells of snakes (Campbell). In the biblical account Serpent is reviled above all other animals, punishment for having revealed the tree of knowledge. By the commandment of Lord God, there exists "enmity" between Snake and Eve and between her seed and the seed of the Serpent. The descendants of Eve will "bruise" the head of all future snakes, and all future snakes will "bruise" our heel (Gen. 3:15). Snake is cursed by its lowliness, by its constant, unremitting contact with earth, which is colored as negative. How different this from the Hopi and Pueblo insistence that Snake is sacred and from the Hopi Snake Dance, in which the participants befriend and dance with living rattlesnakes.

Rattlesnakes seem to be honored in many Pueblo tribes surrounding Santa Fe, often including ceremonies closed to outsiders. The reverence can be strong. Leslie Marmon Silko, the great Laguna Pueblo novelist, has spoken often of her fondness 
of snakes, and I happened to hear her speak on the topic several years ago in Santa Fe. Silko talked of living in an old Adobe house in Albuquerque that was blessed by having several rattlesnakes living underneath the floorboards of the kitchen. Whenever she went to make herself a cup of tea, the floor creaking under her weight, she could hear the snakes' fearsome rattle.

One day she found a large rattlesnake tangled in a fence at the edge of the yard. The snake had been caught by some string or kite wire, which had become tangled in the fence. Silko could not leave a sacred snake there to die. So she spoke to it patiently, asking it not to sting her with its bite, and then gently untangled the string from its body with the help of a pair of scissors she carried from the house. When the snake crawled off, she said, it looked back to her, as if to say thank you.

In the ancient world, the Greeks and Romans spoke of a genius loci, the spirit of a place. We live in an era of the placelessness, of what Howard Kunstler has called "The Geography of Nowhere." Santa Fe is still a place where one can encounter the spirit of place, the genius loci. We have no time to explore the history of this idea, that each place has a genius, but it was still alive well into the Enlightenment, when Alexander Pope advised his friends when planning a garden to "consult the genius of the place in all" (57). In a beautiful garden, it was the genius, Pope said, who orchestrated the design. If we wish to trace the spirit of place in Northern New Mexico, we might do well to observe whom the spirit has attracted: the Santa Fe and Taos art colonies, for instance, or visionaries such as Mabel Dodge Luhan, D. H. Lawrence, and C. G. Jung, all of whom came to Northern New Mexico as refugees from modernity. Chellis Glendinning spoke of being in recovery from Western Civilization (ix-x).

The point is not to move or even visit Santa Fe to experience its spirit of place, and even less to impose its genius loci on other regions of the country, which would be a great absurdity. Each region has its own spirit of place, which must be recovered and renewed, a work that cannot even begin until we first reconstruct the idea of genius loci and its historical importance. The idea must be saved before the idea can save the culture.

When Mabel Dodge Luhan moved to Santa Fe in 1919 she was already one of the most prominent art patrons of the early $20^{\text {th }}$ century and a central figure in the Armory of the Arts Show that brought European modernism to the United States. She was a champion of Gertrude Stein and Pablo Picasso, both close friends, and the mistress of John Reed, the chronicler of the Russian Revolution. It was Luhan who brought Jung, Willa Cather, D. H. Lawrence, and Georgia O'Keefe to New Mexico, part of a fantasy of creating a literary art colony that would save "white man's civilization" by building a new American consciousness from uniquely American soil. In her words, in New Mexico 
the land is still a source of inspiration. Out of a reverence for the soil and the wonder of fertility have grown the great rituals of the American Indian. . . . And linked with these, the mysteries of propagation and of the fiery energies of the human ... have blended and fused into the pattern of existence that is at the same time both life and art. (qtd. in Rudnick 184)

Like Luhan, D. H. Lawrence came to New Mexico to discover "the ancient blood-consciousness" that had been lost elsewhere. As for Jung, who arrived in 1925, he found Antonio Mirabal, an intimate of Luhan and Lawrence whom Jung mistakenly (and somewhat ridiculously) believed to be a Hopi chief. Jung was clueless about Indians, but his eyes were opened by Mirabal a few days after Jung watched a Buffalo Dance at Taos Pueblo. As the two men stood on the roof of a house, looking over the Taos plateau in the bitter cold, Mirabal spoke of the "white man's disease." The white men were so "mad," Mirabal said, that they believed they thought with their head when everyone knew that human beings think with the heart (Jung, MDR, 246-53).

This is no small business, thinking with the heart. Here we begin to get close to our subject, which is the state of enchantment symbolized by "Santa Fe." Enchantment is a psychological earthiness that refers not to the land itself but to its chthonic element, or what we might call the ground of being. This distinction between the land and the chthonic element is clear among the ancient Greeks, who distinguished between chthon and ge, each word referring to different regions of the earth. While ge suggests the literal earth, that which lies in or beneath the dirt world - the fields, the rooted earth, and its minerals - chthon refers to the earthiness of the underworld, a place of invisibility and depth. ${ }^{\text {iii }}$ The earthiness of Santa Fe is not the fertility of the field or the earthiness of workers who haul in the harvest, ruled by Demeter, but the imaginal ground under the earth, ruled by Hades. "Santa Fe" thus seems to be a fantasy of depth and interiority, of going in and going down, or of recollecting the sacred patterns and mythical experiences that give individual life its meaning — in other words, the re-experience of "Great Time," which is, as Mircea Eliade argued, the purpose of any living spiritual tradition (Eliade 23). ${ }^{\text {iv }}$

As Hillman has shown, there is an old tradition of "thinking with the heart" that refers to a connection with the wisdom of the psyche, or, to put it another way, to thinking that is linked with the imagination. ${ }^{v}$ This seems to explain Jung's profound bond to Mirabal, the man he refers to as Mountain Lake. As Jung explained in a letter to Mirabal, in Europe there were no longer "any interesting religious things ... only remnants of old beliefs" (Jung, Letters, 101-02). For Jung, Europeans lacked the ability to think like Pueblo Indians, which meant to think with the mythic imagination, or what Mirabal had called thinking with the heart. Mythically, it is the heart that awakens the fiery images of the imaginal life. The head is good for other things, for building analytical skills, systems of epistemology, or a critical apparatus, 
but it lacks the ability to work in images. In the Sufi tradition, for instance, the heart is the gateway to the Divine, and it is the theater of the heart that awakens the body of the imagination. Among the Sufi's we find a complete ontology of mysticism, one that sees the Divine as imaginal by nature and understands the heart as the organ of imagination (Corbin 21), much as Mirabal says the heart is the seat of intelligence. ${ }^{\mathrm{vi}}$

So far, I have not suggested anything that has not been clearly understood by the New Mexico Tourism Department, which refers to New Mexico as "the land of enchantment." Its Web site promises adventures "to feed the soul." The youth in New Mexico, however, turn this same slogan on its head, calling their home "the land of entrapment," a fairly common phrase among the young. Why entrapment? Perhaps they sense that New Mexico is haunted by history, historical trauma, xenophobia, and ethnic tension. Yes, New Mexico has a mystique but also high rates of suicide, heroin abuse, and violence. Yes, there is a gritty, earth-based reality but also a lack of opportunity, the sense of family and community as oppressive, the sense that, as some youth have said to me, "If I don't get out now, I'll never leave." This, too, is part of the spirit of the place, the genius loci.

I have just presented one particular view of Santa Fe, based in part on a sort of idealization of Santa $\mathrm{Fe}$ in the public mind. Now I would like to do the opposite, revealing Santa Fe to be something quite different and to suggest that it is this second Santa $\mathrm{Fe}$, the fallen and inadequate city, that carries the libido of the place, its force to attract and give meaning. In this aspect, places are like human personalities in which character is revealed through conflicting impulses and ideas. A person or a city comes alive most fully through complication.

It is easy to simplify, reducing the symbol of a place to a single meaning, and difficult to try to understand the spirit of place as inner divisions seeking simultaneous expression. In this respect, literary criticism is sometimes ahead of psychology, understanding that compelling characters are brought to life through conflict. We might even speculate that the mental conflict makes the development of character possible.

If we imagine a city, like a literary character, to contain internal divisions, we are not committing the pathetic fallacy — reading into a city the same internal life that we see in an individual - but rather understanding that geography and history are full of the same contradictory impulses as human life. These contradictory impulses seek expression, just as those who seek to understand a place find it satisfying to experience its complexity, its unresolved longings. As Leonard Cohen sings, "There's a crack in everything / That's how the light gets in." Seeing the spirit of a place means looking for its cracks. 
Sadly, many of our national stories aim towards the triumphant, stressing everexpanding opportunity, but we might imagine that the genius loci is carried largely in the unacknowledged darkness, the intolerance and brutality of different groups, the destruction of the land, its topsoil, native grasses, the loss of family farms and dairies, all of the complexity of our history that is too easily ignored when we focus on a triumphant national story. As Jung puts it, "[T] he man who takes to the back streets and alleys because he cannot endure the broad highway will be the first to discover the psychic elements that are waiting to play their part in the life of the collective" ( $C W 15$, par. 131).

In Northern New Mexico the spirit of place is expressed not only by the loveliness of mud adobe houses but also by the revulsion felt by governmental officials when they first reached Santa Fe after the annexation of the Southwest in 1847-1848. Many of the territorial officials regarded New Mexico as revolting and impoverished, lacking the cultural sophistication of the East Coast. The private secretary of General Stephen W. Kearny, who marched on Santa Fe, was typical. He wrote in his diary that Santa Fe was a "low, dirty and inferior place" that he found intolerably lewd (qtd. in Wilson 53).

This emotional suspicion of Santa Fe is often more difficult to discern today. In many ways, Santa Fe has become a mecca for those seeking a relationship with the earth, but in the process the city has also become something of a commodity, a refuge where a new image of the earth is both entertained and devoured, often becoming a parody of itself. Architectural historians like Chris Wilson have shown that as early as the 1920s the city began to impose a style of building that, while indigenous to the region, was codified for the sake of attracting a tourist trade, an attempt to use the "myth of Santa Fe" to promote the economy. By the 1980s, a decisive shift took place "toward the manipulation of the myth as a tourism marketing image." Santa Fe was remade as "a Tahiti in the desert, bathed in rosy sunsets, a place of chic style of interior design and a world-class tourist destination" (Wilson 9). In the process, most of the original residents of the city were forced out of their historic adobe homes, whose taxes they could no longer afford. Thus there were two competing impulses, the desire to preserve the local culture and the impulse to create a Santa Fe that responds exclusively to the fantasy of tourists. Old adobes, which had originally been built because they were cheap and functional, became status symbols, and the working class moved out of the city to mobile homes in the villages north of town or to the cheaply made subdivisions along Airport Road, where cinderblock walls were plastered with stucco to appear authentic.

If Santa Fe can be said to have a spirit of place, then, it is tempered by such ironies. Part of the pathos of an old adobe wall may have to do with the endangerment of the culture, the way in which an old adobe wall represents the loss and destruction of traditional life. The terrible beauty of Santa Fe receives its emotional tone not only 
from its beauty but also from its relationship to hundreds of years of colonization, first the brutal repression of the Pueblo people and then the erosion of the SpanishAmerican culture that developed here in the $17^{\text {th }}$ century.

In this way, the image of "Santa Fe" reminds us of the ways we brutalize soul, the way in which we turn soul into a commodity. Santa Fe is thus not only the land of mud houses and ox-blood floors but also the shiny city of faux adobe, electric luminarias, ceremonies performed for tourists rather than participants, a triumph of kitsch over authenticity. This pattern represents a different kind of entrapment. Because "Santa Fe" is Other, it is easily cheapened, turned into a warm fuzzy blanket, a piece of soul that can be bought by those who have no desire to build their own souls. Perhaps the most depressing aspect of Santa Fe as a symbol is its ability to mirror the modern human condition.

To understand the psychological complexities of the image, we might say that the earthiness of Santa $\mathrm{Fe}$ is complicated by the need to make earthiness chic, even the need to cleanse it of its dark power. If New Mexico was once an image of radical rebellion to the American order, a landscape in which one could rediscover the knowledge of the blood, it is now also an image of the genocidal impulse to whitewash that rebellion, to make it safe for cultural conquest. There are thus two strands in the spirit of place in Northern New Mexico. One is related to the indigenous, the culture of kiva and Pueblo and of the Spanish colonists who borrowed so much from Native American culture. The other strand, which relates to the diarist who travelled with General Kearny in 1847, is the desire to purify and modernize, to make Santa Fe efficient. The pathos of the place lies in the struggle between these two points of view.

New Mexico in this sense is an almost perfect strain of American Gnosticism, whose genius is permeated by a lasting sense of the finite and flawed, sorrow and despair. Its ethos of inadequacy is rooted not only in its history, with its atrocities and blunders, but also in its hopelessness, parochialism, political corruption, and scarcity of resources.

It is by no accident that the second largest pilgrimage site in the United States lies twenty-six miles north of Santa Fe in the village of Chimayo, where the chief rite takes place each year on Good Friday, when some 20,000 Catholics walk long distances to a sanctuary. Good Friday is not a day of light but of darkness, a day celebrating not the risen Christ but the crucifixion of Jesus, which symbolizes the holy brokenness of the world.

There are those who would prefer to ignore this side of "Santa Fe," who see the colonial side of the city as irrelevant. They prefer to focus on the positive and hopeful side of the region, the way in which New Mexico represents to them the nourishment provided by the sipapu. For them, Santa Fe carries the significance of Mother Earth who is seen as a counterbalance to the environmental degradation of the world. All 
of this is important and true. But Santa $\mathrm{Fe}$ is both places at once, the colonizer and the colonized, the indigenous soul and the genocidal impulse to eradicate it. Romanticizing its Native American background sentimentalizes its troubled history, erasing our dark past for the sake of making it comfortable. For there can be no relationship with the Earth in the $21^{\text {st }}$ century that does not also carry a profound awareness of the ways we have tried to escape our responsibilities to it.

Santa $\mathrm{Fe}$ is thus a symbol of ambivalence and woundedness, an image signifying aspects of the deep feminine and the many defenses against her powers. The mystique of Santa Fe is not just an enchantment but also a complex resistance to that enchantment, a tendency to run from it and to turn its power into kitsch.

\section{Works Cited}

Bernstein, Jerome. Living in the Borderland: The Evolution of Consciousness and the Challenge of Healing Trauma. Routledge, 2005.

Burkert, Walter. Greek Religion. Harvard UP, 1985.

Campbell, Joseph. The Power of Myth with Bill Moyers. "Program Three: The First Storytellers," Highbridge, 2007. DVD.

Cohen, Leonard. "Anthem.” The Future. Columbia, 1992. CD.

Corbin, Henry. The Voyage and the Messenger, Iran and Philosophy. North Atlantic Books, 1998.

Eliade, Mircea. Myths Dreams and Mysteries. Harper, 1975.

Glendinning, Chellis. My Name Is Chellis Glendinning and I'm in Recovery from Western Civilization. New Catalyst Books, 2007.

Hillman, James. The Dream and the Underworld. Harper, 1979.

The Thought of the Heart \& Soul of the World. Spring P, 1981.

The Holy Bible, Revised Standard Version. Penguin Books, 1974.

Jung, C. G. The Collected Works of C. G. Jung. Ed. Sir Herbert Read et al. Trans R. F. C. Hull. 2nd ed. Princeton UP. 1953. 20 vols.

_. Jung Letters. Eds. Gerhard Adler and Aniela Jaffe, volume 1, Princeton UP, 1972.

. Memories, Dream, Reflections. Translated by Richard and Clara Winston. Princeton UP, 1963.

Kunstler, Howard. The Geography of Nowhere: The Rise and Decline of American's Man-Made Landscapes. Free Press, 1994.

Pope, Alexander. "Epistle IV, to Richard Boyle, Earle of Burlington." London, 1731.

The Power of Myth with Bill Moyers. "Program Three: The First Storytellers." 1988. DVD, Mystic Fire, 2001.

Rudnick, Lois. Mabel Dodge Luhan: New Woman, New Worlds. U of New Mexico P, 1984.

Wilson, Chris. The Myth of Santa Fe: Creating a Modern Regional Tradition. U of New Mexico P, 1997). 


\section{Notes}

${ }^{\mathrm{i}}$ For this idea I am indebted to Doug Belknap, who introduced me to the concept of differentiating between Santa Fe and "Santa Fe" sometime in the late 1990s.

${ }^{\text {ii }}$ For a full study of the cult of the dead in ancient Greece, see Walter Burkert, Greek Religion (190-215).

iii For a psychological exploration of the Greek words ge and chthon, see James Hillman, The Dream and the Underworld (5).

iv Some of Eliade's work is controversial today, but his theory of "Great Time" remains widely used in the study of religion.

"See Hillman's explication of this theme in "The Thought of the Heart," originally a lecture given at Eranos in 1979. The published version can be found in James Hillman, The Thought of the Heart \& Soul of the World.

vi The Sufi understanding of mysticism seems to be derived from Sura 2.2 which defines Muslims as those who see the unseen. For many Sufi's the organ for seeing the unseen is the heart. 